\title{
PERFORMANCE AND LEADERSHIP STYLE: WHEN DO LEADERS AND FOLLOWERS DISAGREE?
}

\section{MARIA APARECIDA MUNIZ JORGE DIAS}

Master's Degree in Business Administration from the Department of Management, Federal University of Minas Gerais (UFMG).

Specialist in Public Policy and Governmental Management at the Department of Management, Federal University of Minas Gerais (UFMG).

Central Director of Performance Management at the Planning and Management Secretariat of the State of Minas Gerais.

Avenida Antônio Carlos, 6627, Pampulha - Belo Horizonte - MG - Brasil - CEP 31270-901

E-mail: mariamuniz2@yahoo.com.br

\section{RENATA SIMOES GUIMARAES E BORGES}

$\mathrm{PhD}$ in Business Administration from the Department of Management,

Federal University of Minas Gerais (UFMG).

Assistant Professor at the Department of Management,

Federal University of Minas Gerais (UFMG).

Avenida Antônio Carlos, 6627, Pampulha - Belo Horizonte - MG - Brasil - CEP 31270-901

E-mail: renatasg@face.ufmg.br 


\section{ABSTRACT}

Purpose: The goal of this research is to analyze how team performance is influenced by leadership styles in the public sector, confronting the perspectives of the leaders with the perception of their teams.

Originality/gap/relevance/implications: The main contribution of this study is to compare the perspectives of leaders and followers in the same context. Furthermore, this research investigates the relationship between team performance and style of leadership in the public sector. This research offers empirical data that can support the development of human resources policies and practices directed at improving leadership and reduce the gap between leaders and followers.

Key methodological aspects: The survey method was used to collect data in the Executive Branch of State of Minas Gerais, which was answered by 315 individuals. We applied standardized questionnaires based on well tested instruments available in the literature.

Summary of key results: The results indicate that leaders feel that team performance is directly influenced by transformational leadership, supporting the literature. For the followers, the level of team performance is directly influenced by the transactional characteristics of the leaders and not transformational characteristics. The results also suggest that the performance evaluation run by the government might be overvalued, since leaders and non-leader employees think that their own team performance is lower than the officially measured performance.

Key considerations/conclusions: The idiosyncratic dynamics of people management of the Executive Branch of Minas Gerais reinforce behaviors that require leaders to use transactional leadership style. However, when managers achieve upper levels, the transformational style seems to be better suited to improve the other managers' performance.

\section{KEYWORDS}

Leadership. Leadership styles. Performance. Team performance. People management. 


\section{INTRODUCTION}

Performance management systems in general focus on three levels of analysis: organizational, team and individual (Brannick \& Prince, 1994). At the individual level, the aim of the evaluation is the result of the individual's activities, tasks and/or behavior in the work environment. The individual evaluation is developed to keep or enhance the quality of products and services as the evaluation seeks for organizational productivity. How organizations employ performance measurement systems at these three different levels depends on their maturity level regarding planning processes and measurement tools.

In the Executive Branch of State of Minas Gerais in Brazil, a performance measurement system was implemented within the three levels. To measure performance at the organizational and team levels, state government developed and implemented a system named Results Agreement (AR). The $\mathrm{AR}$ is an instrument in which the results are negotiated in the Executive Branch between governmental units, managers of administrative units, and authorities who have hierarchical power over them (Duarte, Lemos, Marini, \& Martins, 2006).

The individual-level measurement is conducted through the performance evaluation process regulated by State Complementary Law no. 71, dated July 30, 2003. All non-management employees are evaluated based on criteria that assess their competence to execute the tasks under their responsibility. This evaluation has undergone some reformulations and, since 2013, has been conducted based on the criteria established in Resolution SEPLAG no. 001 , which are: 1 . focus on results, 2 . focus on customer, 3. innovation, 4. teamwork, and 5. professional commitment.

The employees who are going to be evaluated as well as their supervisors are equally responsible for indicating the members of the evaluation committees. These committees conduct the individual performance evaluations annually. The results of the individual evaluations are used in the career promotion system, to compute the bonuses payment, to support the dismissal processes, and as an input to training policies (Ribeiro, Chaves, Gama, \& Dias, 2011).

The case of Minas Gerais demonstrates that the modernization movement of public administration brings with it the need to discuss managerial changes, specifically regarding performance and its relation to leadership (Martins, 2014). In this context, the leader is seen as a leading actor for the development of organizational capacities and competitive advantages (Ulri- 
ch \& Lake, 1990). The leader helps to create meaning, builds shared perceptions towards organizational reality, and fosters commitment based on the motivational dynamics of the followers (Bergamini, 1994). In sum, the leader may be responsible for building the directions of the organizational future (Hamel, 1997).

In general, employees in leadership positions become responsible for developing and maintaining motivational features in their followers, seeking superior organizational performance (Sant'anna, Campos, \& Lótfi, 2012). The leader may develop a relationship with his/her followers based on the ability to constantly encourage the team (Niemeyer \& Cavazotte, 2016). In this sense, leaders are able to influence their team more easily, preparing them for the processes of change which have been part of every organizational context (Marques, Borges, Morais, \& Silva, 2014).

Even in the public sector, achieving leadership positions involves greater responsibility and pressure for results. Considering the relatively recent changes through which the public sector in Brazil has been going, it is important to analyze the role of public employees as leaders (Oliveira, Sant'Anna, \& Vaz, 2010). However, most studies on leadership in the Brazilin public context focuses on either leaders' views or followers' perspectives. The main contribution of this study is to compare the perspectives of leaders and followers in the same context. Furthermore, this research investigates the relationship between team performance and style of leadership in the public sector.

The goal of this research is to analyze how team performance is influenced by leadership styles in the public sector, confronting the perspectives of leaders with the perception of their teams. This work contributes to the literature by deepening the understanding of the effects of leadership styles on team performance in the Brazilian public sector. To managers and practitioners, this research offers empirical data that can support the development of human resources policies and practices directed at improving leadership and reduce the gap between leaders and followers. This study also provides support for other Brazilian states or governments in general that have implemented or will implement performance evaluation systems. In practice, the effects of performance evaluations in other HR systems (such as rewards, training and career development) in Brazilian public administration depend heavily on factors, such as state budget and political influence, for example. In this context, a leader's performance becomes central, because on the one hand it can improve team's performance by motivating its members or, on the other hand, it can make the team's performance unsatisfactory, compromising the quality of public services delivered to the population. 


\section{THEORETICAL FRAMEWORK}

\subsection{Leadership styles}

One of the great challenges of leaders is to direct the potential of human capital towards the achievement of organizational goals and results. As the importance of teams grows in the organizational environment, so does the role of the leader who guides their team. Leaders cannot solve problems alone. The complex world requires a combination of resources and skills from several employees. For these reasons, strong emphasis is placed on the promotion of teamwork and strong leadership (Jones \& Rudd, 2008).

The exercise of leadership requires the consent of subordinates to the leader. In this context, leadership only exists after being recognized by other members of the group. Leaders tend to emerge as different from followers in their ability to initiate and maintain interaction. These leaders serve to increase the participation of members with less ability, accept diverse personalities, and are very tolerant to deviations (Bass, Avolio, Jung, \& Berson, 2003). In this sense, the relationship between leaders and followers creates a basis for the beginning of the studies on transactional leadership (Van Seters \& Field, 1990). The transactional leader is a negotiator, who establishes agreements in exchange for desired results. The transactional leader can both reward for satisfactory performance and punish unmet goals (Fonseca, Porto, \& Barroso, 2012).

The most recent and promising phase in the evolution of leadership theory is represented by the so-called transformational era. Transformational leadership refers to the inspirational leader who is capable of achieving high team performance by intellectually encourage their followers, offering individualized support (Fonseca et al., 2012). The dramatic improvement of this era over the past eras lies in the fact that transformational leadership is based on intrinsic motivation, rather than on extrinsic motivation (Van Seters \& Field, 1990). Moreover, in comparison to the transactional era, leaders must be proactive rather than reactive in their thinking. Leaders are more radical than conservative, more innovative and creative, and more open to new ideas (Bass, 1985). The goal of this style of leadership is to influence and produce enthusiastic commitment, as opposed to reluctant obedience or indifferent fulfillment (Yukl, 1989).

According to this approach, followers assign heroic or extraordinary abilities to leadership when they observe certain behaviors. Research has devoted much attention to the search for characteristics that distinguish leaders 
considered charismatic. One of the most notable studies is the one developed by Conger and Kanungo (1987) that indicated that transformational leaders have an idealized goal, strong personal commitment to their goal, are perceived as unconventional, assertive and self-reliant, and are agents of radical change rather than status quo keepers.

Finally, the laissez-faire style of leadership is characterized by the leader interfering little in the decisions of the group, giving freedom for the employees to make the decisions. In this sense, the leader avoids clarifying his/her expectations and resolving conflicts, as well as shifts his/her authority to the followers, deliberately abdicating the power to make decisions, which are delegated to the followers (Bass \& Avolio, 2000).

The task of leadership thus becomes a construction, monitoring and reinforcing a culture of high expectations. This philosophy was disseminated by Bass (1985) who suggested that work groups tend to choose leaders and that they hope to ensure the task is accomplished, to maintain strategic focus, and to facilitate group cohesion. Therefore, subordinates move away from concerns of membership and security and move onto self-realization, realization and recognition concerns, thus improving individual and team performance.

\subsection{Team performance and leadership styles}

Performance is a complex concept that can be defined as a set of parameters or indicators that are complementary, and sometimes contradictory, that describes the assessment process through several types of achieved results (Lebas \& Euske, 2002). In this sense, performance almost always depends on identifying a causal model that describes how actions today can influence outcomes in the future. Therefore, performance measurement becomes an important indicator only if the organization has acquired the knowledge and mastery of its causal relationships to reproduce this result in the future. The term performance must be used to represent the sum of all processes leading to a potential or future sequence of results.

For Dutra (2010), performance can be expressed as the set of deliverables and results generated by the development, effort and behavior of the employee in the organization. The level of development of the employee is related to his/her maturity and autonomy of action, and determines the organization's expectation about his/her performance. The effort, however, differs from the level of development due to the quality of the value added to the organization. Effort is a contingency, and is linked to the motivation of the individual and the favorable conditions offered by the organization or 
the market, at that moment. No one can guarantee that a strenuous person today will continue to be so tomorrow. Finally, behavior may or may not affect the development and effort of the employee and is related to a pattern of behavior defined by the organization or set of people (Dutra, 2010).

Murphy (2008) considers that the best way to use performance assessment is as part of a set of convergent measures that, applied together, are more likely to capture variation in work performance than if used alone. In this sense, Fernandes (2013) suggested an integrated model of performance evaluation that captures several dimensions. The model is characterized by assessments of inputs and outputs. Inputs are assessed based on capabilities, which may be knowledge, skills, attitudes, and values. Knowledge and skills do not require systematic evaluation, since they are recorded in professional experience, in terms of accumulated training that can be validated through certificates. Outputs are evaluated in terms of results evaluated as competencies and goals achievement, which are measured by indicators within a target system. The results are analyzed by self-assessment and by superiors, evaluated in terms of indicators, and then stored and made available in operational systems.

Team performance and even the organizational performance are usually tied to the effectiveness of leadership. Hogan, Curphy and Hogan (1994) suggested that leadership effectiveness should be measured in terms of group, team, or organizational effectiveness. This is because the social relations built in the organizational context can influence the perceptions of effectiveness and leadership, by the meanings attributed and reconstructed by the group. The meanings shared by the team depend on the language used and the communication, being realized through sense making, that is, a collective creation of meaning (Weick, Sutcliffe, \& Obstfeld, 2005). The social systems developed within the organization are constant inputs for employees to interpret and reinterpret their experiences. Situations previously considered right can be reinterpreted and modified to meet new collective expectations (Weick \& Roberts, 1993).

Laine, Korhonen and Martinsuo (2016) added that the social process of sense making occurs at both managerial and team levels. Formal managers or leaders are more likely to develop mental representations that translate organizational patterns of values and beliefs (Hodgkinson \& Healey, 2008). As a result, leaders become more committed to organizational results, mainly due to their differentiated perception of the status quo. The other team members, although they may have a differentiated perception regarding the leader, tend to present more homogeneous patterns of behaviors and beliefs. As the simulation of Dionne, Sayama, Hao and Bush (2010) illustrates, mental 
models of team members converge when there is mutual interest and leadership. The authors concluded that whenever mutual interest among the followers is high, teams converge into mental models in all conditions of leadership. The values, cognitions, perceptions, behaviors, and attitudes common to team members characterize the shared properties of the team. Klein and Kozlowski (2000) explained that among the properties shared by team members are perceptions of leadership style and performance.

However, if leadership effectiveness assessments are influenced by individual perceptions, there is evidence that leadership effectiveness classifications converge with objective measures of group work performance, providing support for the use of supervisor and subordinate classifications, such as leadership effectiveness measures (Judge, Bono, Ilies, \& Gerhardt, 2002). For example, Moynihan, Wright and Pandey (2012)'s studies of the effects of leadership on bureaucracy indicated that transformational leaders improved internal communication, received political support, and conveyed the organizational goal with clarity, reducing the effects of excess standards and rules in the team. In practice, however, leadership effectiveness assessments most commonly consist of ratings made by leader's supervisor or subordinates (or some combination of these). Such assessments, while representing the predominant method of assessing leadership effectiveness, may be criticized as potentially contaminated. This is because they represent individual perceptions rather than objectively examining performance.

In general, research that relates the characteristics of leaders to organizational results has consistently found positive results. Ross and Offermann (1997) found a positive effect of transformational leaders' personality attributes on subordinate satisfaction. Somech (2006) found that leadership styles and participatory leadership directly impact the process of functioning of a heterogeneous team, promoting team reflection and innovation. Shen and Chen (2007) showed that leadership had a positive effect on team confidence and performance in a large-scale study conducted in Taiwan's manufacturing and service industries. Finally, research by from Tost, Gino and Larrick (2013) indicated that the psychological effect of a leaders' formal power negatively affected team performance. This is because verbal dominance, often resulting from the leader's elevated leadership experience, reduces team communication, negatively impacting performance.

In sum, previous studies show that leadership plays a key role on team performance. In public administration, it is expected that the influence of leaders in their teams will be lower due to the lack of autonomy to reward, punish, hire, and fire. Even so, the leadership style most associated with the best performance is the transformational, as the literature points out. 
Because the transformational leader is proactive, innovative, and creative, he/she can motivate his/her team to get better results, thereby improving performance. In both views, leaders and followers, the transformational leadership style is more likely to be positively associated to higher team performance.

\section{METHODOLOGY}

This research is explanatory in nature, as it seeks to establish relations between variables, serving as a basis for explaining the phenomena described (Gil, 2008). The survey method was used to collect data, because a sample can be used to make inferences about attitudes, behaviors and characteristics of a population (Creswell, 2013). The survey allows the employment of rigorous statistical tests to verify empirical propositions related to the relationship of variables, and to carefully examine the relative importance of each one (Babbie, 2015).

This research identifies the leadership styles of the executive, autarchic and foundational administration to explain the hypothesized relationships between team performance and leadership styles, using a quantitative approach. According to Collis and Hussey (2005), a quantitative study is characterized by transforming opinions and information into numbers that enable the classification and analysis of the data collected in the applied instruments.

The population for the research consists of middle managers of 58 units and entities of the executive, autarchic and foundational administration of the Executive Branch of Minas Gerais, who take part in the performance evaluation practice. Performance evaluation on managerial positions assesses team leadership as a required competency; all managers are expected to be good leaders besides executing their administrative tasks. The top management positions, which are not included in our sample, corresponds to the positions of State Secretary, Deputy Secretary and Vice Secretary, and in the autarchic and foundations, corresponds to the positions of General Director and Vice General Director, President and Vice President, Chancellor, and Vice Chancellor. The performance evaluation of public managers is regulated by Decree no. 44,986, of December 19, 2008. It was developed based on the profile of the required managerial competencies, which includes: 1. results orientation, 2 . systemic vision, 3 . people management, 4 . team leadership, 5. innovative behavior, 6 . knowledge and information sharing, and 7. technical competence. 
In this research, the sample was obtained randomly in order to ensure that the selected teams adequately represent the population of leaders surveyed. We ran the power analysis to compute the sample size, a test that seeks to minimize statistical error $(\alpha)$, directly relating sample size and expected effect size. Thus, using GPower software, version 1.3.5, assigning a power of $80 \%$, for an expected effect of 0.15 , a $5 \%$ error and 3 predictors (that is, three leadership styles) we needed at least 77 teams.

Before applying the questionnaires, a form of control was created and allowed the respondents not to be identified, but at the same time, it was possible to relate his/her responses to each leader assessed. A questionnaire with a specific link was created in Google Docs for each leader and for each team. As result, we were able to aggregate team members by identifying their respective leaders. Therefore, the measures of teams were accessed through the individual responses of each of its members. Klein and Kozlowski (2000) explained that it is possible to measure some characteristics of teams, such as perceptions about leadership and performance, collecting individual data from their members and then aggregating them into a single measure. The authors explained that it is possible to aggregate the data when there are common properties shared between team members, since those properties are constructed through socio-cognitive processes.

The questionnaires were sent via email, with an explanation of the purpose of the research. The questionnaire was answered by 315 individuals, of whom 233 were employees and 82 were team leaders, representing a sample of 82 teams, exceeding the minimum required.

\subsection{Data research and analysis instrument}

The questionnaire was composed of three parts. In the first part, to identify leadership styles, 21 questions were used from the Multifactor Leadership Questionnaire (MLQ) developed by Bass and Avolio (2000). The MLQ contains 21 items that measure the range of leadership behaviors. It has been repeatedly validated, and is strongly predictive of leader performance (Bass, 1985). The items are measures of leadership styles and behaviors which range from transactional leadership to transformational leadership, including laissez-faire behavior. According to Bass and Avolio (2000), the reliability of MLQ for each leadership factor ranges from .74 to .91. It is the most widely used instrument to assess leadership styles (Kirkbride, 2006) and is considered the best validated measure of transformational and transactional leadership (Özaralli, 2003). The scale used in this part is ranges from zero to four, with 0 (never) 1 (rarely), 2 (sometimes), 3 (often), and 4 (always). 
The second part of the questionnaire, consisting of 24 questions, was constructed based on expected performance established by SEPLAG Resolution no. 001, dated January 3, 2013. The performance of the teams was measured across five aspects or variables: 1 . focus on results, 2 . focus on customer, 3. innovation, 4. teamwork, and 5. professional commitment. The measurement items of performance were adapted because in this research they were used as one dimension of the team performance variable, according to the model proposed by Fernandes (2013). In this regard, it is important to highlight that, although the unit of analysis of the performance evaluation system in Minas Gerais is the individual, in this survey, the level of team performance was assessed, since even the government focuses on teamwork to achieve required goals, and employees depend on each other to deliver the expected results. Thus, the quality of results requires a team effort (Margerison, Dick, \& Davies, 1995).

In the second section, we used a 5-point Likert scale ranging from 1 (totally disagree), 2 (disagree), 3 (neither agree nor disagree), 4 (agree) to 5 (totally agree). According to the measurement instrument, different weights were assigned for each item to compute the variables. Finally, the last part of the questionnaire was the respondents' demographic data. On the first page of the questionnaire, a cover letter informed the research objectives, ensuring respondent anonymity, as well as voluntary participation in the study.

The results of validity, reliability and internal consistency measures of the applied questionnaire - the measurement model for this sample - are described in the appendix of this paper. The factorial loading of each item were higher than \pm 0.50 , which is the threshold for practical significance (Hair, Black, Babin, Anderson, \& Tatham, 2006). Convergent validity also shows that the items share a high proportion of variance among them, greater than $50 \%$. And, finally, the values obtained of internal consistency, measured by Cronbach's alpha, indicate that the items converge to their respective construct, the values obtained were greater than .71.

Secondary data on team performance measured by the state government, were obtained through the State Department of Planning and Personnel Management. According to the official evaluation system, each team can obtain an annual score between 0 and 100. These indicators measure performance that varies from client satisfaction to execution rate of specific projects.

Analyses of variance were performed to identify the differences between the leadership style in the leaders' view and leadership style in the followers' perspective. Analysis of variance was also employed in the results of 
team performance to evaluate whether the perceptions of leaders and followers differ. The Welch test was reported because the assumption of homoscedasticity was not met. The correlation analysis was reported using the Pearson Product Moment correlation coefficient. Therefore, from the answers of participants of the research, two multiple regressions were employed. The first one involves independent variables - leadership styles - and the dependent variable - performance of the teams, in the leader's view. The second multiple regression analysis takes into account only the perspective of followers. Finally, we used an analysis of variance to compare the performance measures collected in the questionnaires (primary data) to the government official measures of performance (secondary data). The statistical analysis was performed using the Statistical Package for the Social Sciences - SPSS for Windows 16.

\section{RESULTS}

The results of the analysis of variance indicate that leaders and followers have a different perception of leadership styles, as shown in Table 1. To the leaders, the predominant style of leadership is transformational $(\mathrm{M}=9.41$, $\mathrm{SD}=1.79)$, followed by the transactional $(\mathrm{M}=8.75, \mathrm{SD}=1.50)$, and laissez-faire $(\mathrm{M}=5.56, \mathrm{SD}=2.21)$. To the followers, both the transactional leadership style $(M=6.34, \mathrm{SD}=2.75)$ and the transformational style $(\mathrm{M}=$ $6.31, \mathrm{SD}=3.47$ ) are predominant in the public administration, followed by laissez-faire $(\mathrm{M}=5.96, \mathrm{SD}=2.53)$.

Comparing the perspectives of leaders and followers, there is a significant difference in relation to the transformational $(F[1,271.72]=106.0, p$ $<.001)$ and transactional styles $(F[1,259.73]=97.26, p<.001)$. Followers feel that leaders administrate less by exception and offer fewer contingent rewards than the leaders think they do. This difference is greater in relation to the transformational dimensions. Leaders think they are more idealizing, motivating, and offer better individualized consideration than the followers think they are. With regard to laissez-faire style, the perceptions of leaders and followers do not differ $(F[1,161.12]=1.78, p=.182)$.

Table 2 shows the results of perceived performance of leaders and followers for each dimension. In general, the leaders have a better perception of team performance $(\mathrm{M}=19.97, \mathrm{SD}=2.32)$ than the followers $(\mathrm{M}=17.85$, $\mathrm{SD}=3.73)$, and this difference is statistically significant $\left(F\left[\begin{array}{ll}1 & 132.36\end{array}\right]=\right.$ $28.80, p<.001)$. The largest difference regards teamwork. Leaders think that followers work more in teams than they actually do. 


\section{(Table 1)}

RESULTS OF PERCEPTIONS OF LEADERSHIP STYLES

\begin{tabular}{lcccc}
\hline & \multicolumn{2}{c}{ Leaders } & \multicolumn{2}{c}{ Followers } \\
\cline { 2 - 5 } Leadership styles & Mean & $\begin{array}{c}\text { Standard } \\
\text { deviation }\end{array}$ & Mean & $\begin{array}{c}\text { Standard } \\
\text { deviation }\end{array}$ \\
\hline Transformation leadership & 9.41 & 1.79 & 6.31 & 3.47 \\
Idealized influence & 9.16 & 1.78 & 6.59 & 3.8 \\
Inspirational motivation & 9.65 & 1.86 & 6.59 & 3.49 \\
Intellectual stimulation & 9.39 & 2.25 & 5.99 & 3.6 \\
Individual consideration & 9.46 & 2.13 & 6.09 & 3.64 \\
\hline Transactional leadership & 8.75 & 1.5 & 6.34 & 2.75 \\
Contingent reward & 8.48 & 2.07 & 5.38 & 3.32 \\
Administration by exception & 9.02 & 1.41 & 7.3 & 2.66 \\
\hline Laissez-faire & 5.56 & 2.21 & 5.96 & 2.53 \\
\hline
\end{tabular}

Note: $\mathrm{N}=82$ for the leaders and $\mathrm{N}=233$ for the followers. The maximum score is 12 .

Source: Elaborated by the authors.

\section{(Table 2)}

RESULTS OF TEAM PERFORMANCE

\begin{tabular}{|c|c|c|c|c|c|}
\hline \multirow[b]{2}{*}{ Perfomance } & \multirow[b]{2}{*}{ Group } & \multirow[b]{2}{*}{ Mean } & \multirow[b]{2}{*}{$\begin{array}{l}\text { Standard } \\
\text { deviation }\end{array}$} & \multicolumn{2}{|c|}{$\begin{array}{c}\text { Confidence Interval } \\
(95 \%)\end{array}$} \\
\hline & & & & $\begin{array}{l}\text { Lower } \\
\text { limit }\end{array}$ & $\begin{array}{l}\text { Upper } \\
\text { limit }\end{array}$ \\
\hline Team performance & $\begin{array}{l}\text { Leaders } \\
\text { Followers }\end{array}$ & $\begin{array}{l}19.97 \\
17.85\end{array}$ & $\begin{array}{l}2.32 \\
3.73 \\
\end{array}$ & $\begin{array}{l}19.30 \\
17.33\end{array}$ & $\begin{array}{l}20.54 \\
18.36\end{array}$ \\
\hline Focus on results & $\begin{array}{l}\text { Leaders } \\
\text { Followers }\end{array}$ & $\begin{array}{l}24.80 \\
22.08\end{array}$ & $\begin{array}{l}3.06 \\
4.97\end{array}$ & $\begin{array}{l}24.01 \\
21.44\end{array}$ & $\begin{array}{l}25.59 \\
22.72\end{array}$ \\
\hline Focus on clients & $\begin{array}{l}\text { Leaders } \\
\text { Followers }\end{array}$ & $\begin{array}{l}16.88 \\
15.56\end{array}$ & $\begin{array}{l}2.05 \\
3.20\end{array}$ & $\begin{array}{l}16.40 \\
15.14\end{array}$ & $\begin{array}{l}17.35 \\
15.97\end{array}$ \\
\hline Innovation & $\begin{array}{l}\text { Leaders } \\
\text { Followers }\end{array}$ & $\begin{array}{l}20.88 \\
18.73 \\
\end{array}$ & $\begin{array}{l}2.11 \\
4.06 \\
\end{array}$ & $\begin{array}{l}20.36 \\
18.21 \\
\end{array}$ & $\begin{array}{l}21.39 \\
19.25\end{array}$ \\
\hline Team work & $\begin{array}{l}\text { Leaders } \\
\text { Followers }\end{array}$ & $\begin{array}{l}24.70 \\
21.91\end{array}$ & $\begin{array}{l}3.47 \\
5.10\end{array}$ & $\begin{array}{l}23.82 \\
21.26\end{array}$ & $\begin{array}{l}25.57 \\
22.57\end{array}$ \\
\hline Professional commitment & $\begin{array}{l}\text { Leaders } \\
\text { Followers }\end{array}$ & $\begin{array}{l}12.36 \\
10.97\end{array}$ & $\begin{array}{l}1.79 \\
2.66\end{array}$ & $\begin{array}{l}11.91 \\
10.62\end{array}$ & $\begin{array}{l}12.81 \\
11.30\end{array}$ \\
\hline
\end{tabular}

Note: $N=82$ for the leaders and $N=233$ for the followers. The maximum score is 30 . 
The correlation analysis indicates that, in the leaders sample, there is a positive correlation between team performance and transformational leadership styles $(r[56]=.515, p<.001)$, and transactional style $(r[56]=$ $.470, p<.001)$. However, there is no correlation between performance and laissez-faire style $(r[56]=.103, p=.451)$. For the followers sample, there is a correlation between team performance and transformational $(r[232]=$ $.535, p<.001)$, transactional $(r[232]=.567, p<.001)$ styles, and laissez-fai$r e(r[232]=.227, p<.001)$ style.

A multiple regression analysis (stepwise method) was then conducted to identify how leadership styles influence team performance, for both leaders and followers samples. The result of the regression analysis suggests that regarding leaders' perceptions, only the transformational leadership style $(\beta=0.515, p<.001)$ influences team performance $[F(1,54)=19.52$, $p<.001)$. In this model, $25.2 \%$ of the variation of team performance is explained only by the transformational leadership style. Table 3 shows the results of the regression analysis of leaders and followers.

\section{(Table 3)}

RESULTS OF REGRESSION ANALYSIS FOR LEADERS AND FOLLOWERS

\begin{tabular}{|c|c|c|c|c|c|c|c|}
\hline \multirow[b]{2}{*}{ Coefficients } & \multicolumn{2}{|c|}{$\begin{array}{l}\text { Unstandardized } \\
\text { Coefficients }\end{array}$} & \multicolumn{2}{|c|}{$\begin{array}{l}\text { Standardized } \\
\text { Coefficients }\end{array}$} & \multirow[b]{2}{*}{ Sig. } & \multicolumn{2}{|c|}{$\begin{array}{c}\text { Confidence } \\
\text { Interval (95\%) }\end{array}$} \\
\hline & B & $\begin{array}{l}\text { Std. } \\
\text { Error }\end{array}$ & Beta & $\mathrm{t}$ & & $\begin{array}{l}\text { Lower } \\
\text { limit }\end{array}$ & $\begin{array}{l}\text { Upper } \\
\text { limit }\end{array}$ \\
\hline $\begin{array}{l}\text { Leaders } \\
\text { (Constant) } \\
\text { Transformational } \\
\text { leadership } \\
\text { Transactional leadership } \\
\text { Laissez-faire } \\
\end{array}$ & 14.407 & 1.288 & $\begin{array}{l}0.515 \\
0.154 \\
0.198\end{array}$ & $\begin{array}{l}4.418 \\
0.776 \\
1.703 \\
\end{array}$ & $\begin{array}{l}0.000 \\
0.441 \\
0.094\end{array}$ & 11.83 & 16.99 \\
\hline $\begin{array}{l}\text { Followers } \\
\text { (Constant) } \\
\text { Transformational } \\
\text { leadership }\end{array}$ & 12.956 & 0.510 & & 25.390 & 0.000 & 11.95 & 13.96 \\
\hline $\begin{array}{l}\text { Transactional leadership } \\
\text { Laissez-faire }\end{array}$ & 0.771 & 0.074 & $\begin{array}{l}0.567 \\
0.049\end{array}$ & $\begin{array}{c}10.446 \\
0.850\end{array}$ & $\begin{array}{l}0.114 \\
0.000 \\
0.396\end{array}$ & 0.63 & 0.91 \\
\hline
\end{tabular}

Note: Dependent variable: Team performance.

Source: Elaborated by the authors.

Surprisingly, in relation to the followers' perceptions, the results of the multiple regression analysis (stepwise method) suggest that only the tran- 
sactional leadership style $(\beta=0.567, p<.001)$ influences team performance $[F(1,230)=109.11, p<.001)$. In this case, $32.2 \%$ of the variation of team performance is explained by the transactional leadership style.

The analysis of the results of leaders and followers indicates that there is a difference of perception on how leadership styles influence team performance. Leaders consider that transformational leadership style leads to a higher level performance, confirming the general theory about leadership styles. On the other hand, followers perceive that transactional leadership is the style which leads to better performance in the Brazilian state level administration.

Finally, in order to analyze the differences between the official performance evaluation employed annually by the government (secondary data) and the performance measured in this research (primary data), we performed an analysis of variance. Since the maximum value of the official measure is 100 , we decided to adjust the second measure to the same scale. The result of the analysis of variance indicates that there is a significant difference between the two measures $[F(1,195)=306.74, p<.001]$, showing that the official performance evaluation shows higher average $(\mathrm{M}=93.40, \mathrm{SD}=$ 8.43) when compared to the performance measured by the researchers ( $M$ $=76.09, \mathrm{SD}=15.00$ ).

\section{FINAL CONSIDERATIONS}

In the last 10 years, the Executive Branch of Minas Gerais has undergone several changes since the implementation of the change management project, which is already in its third generation. A set of managerial tools aimed at modernizing the public management was structured and implemented, with managers being the main drivers of this process. In this context, this survey analyzes how the leadership styles of public managers influence the team performance of employees of the Executive Branch of Minas Gerais, confronting the perspectives of the leaders and followers. The model of Bass and Avolio (2000) was used to analyze the three styles of leadership, i.e. transactional, transformational, and laissez-faire, and the model of Fernandes (2013) was used in relation to performance, goal achievement, and results. Based on these models, we identified the leadership styles existing in the Executive Branch of the state administration, and how these styles influence team performance. It was also possible to compare the measures of official team performance to the data of team performance collected in this survey.

Overall, the literature suggests that transactional and transformational leadership styles positively influence team performance, while the laissez-fai- 
re leadership style, also called non-leadership, negatively influences or does not influence team performance. In relation to transformational and transactional leadership styles, previous research indicates that the transformational leader is more effective in guiding followers towards the achievement of organizational goals and objectives, increasing the level of individual and team performance (Dionne, Yammarino, Atwater, \& Spangler, 2004; Jung \& Avolio, 1999; Moynihan et al., 2012).

However, the results of this survey show that for the State Executive Administration of Minas Gerais, the relationship between leadership and team performance seems not to be as linear as the international literature suggests. The data obtained from 315 employees, of whom 233 were team members and 82 were team leaders, indicates a lack of alignment between leaders and followers. This lack of alignment lies in both perspectives, regarding the perceived level of team performance and the leadership style managers think they have and the leadership style followers actually perceive. In relation to all dimensions of performance (focus on results, focus on the client, innovation, teamwork, and professional commitment), managers perceive that their team performance is greater than the performance perceived by the very same team members.

Leaders feel that team performance is directly influenced by a specific leadership style, while followers think that another style of leadership influences performance. In other words, in the view of managers, they think they act as transformational leaders, guiding, serving as example, motivating, intellectually encouraging their team, and teaching their followers in a coaching way. Managers perceive that employing this style of leadership improves their team's performance.

On the other hand, followers perceive that managers have both transformational and transactional characteristics. That is, in addition to motivating, guiding, and encouraging their team, managers also negotiate, focus on goals and tasks, and reinforce the relationship between performance and rewards. For the followers, the level of team performance is directly influenced by the transactional characteristics of leaders, and not transformational characteristics. When comparing the results of the official performance evaluation to the performance results measured in this survey, we verified that the official performance evaluation is significantly higher than the results measured in this study.

These findings have important implications for theory and practice. For theory, in the context of the Executive Branch of Minas Gerais, the transactional leadership style seems to be more effective for improving team performance. The leadership literature points out that the transformational 
leader develops a closer relationship between leaders and followers, based on trust and commitment to the results. In this sense, leaders who have this style help followers to see the importance of going beyond their own interests, prioritizing the mission and vision of their group and/or organization, producing a strong and positive identification, motivating towards goals achievement (Jung \& Avolio, 1999). On the other hand, the followers do not see so much difference between transformational and transactional leadership styles from the managers. When considering the influence of these styles on team performance, the team members think that transactional leadership style, in which performance/outcome is associated with a reward, is the one that enhance team performance. In sum, the leader who makes clear the link between performance and rewards and provides a constructive feedback to keep followers doing their task (Bass, 1985; Jung \& Avolio, 1999 ) is the most successful on improving team performance. These findings contradict the literature on leadership that has consistently associated the transformational style with higher individual and team performance. Future research may expand the investigations to find why public employees of the Executive Branch of Minas Gerais associate transactional leadership style with higher performance. In addition, whereas other research systematically finds the same results, there will be strong evidence that the literature regarding the relationship between leadership styles and team performance finds its particularity in the public sector of Brazilian state level administration.

The practical implications are varied. We can infer that idiosyncratic dynamics of people management of Executive Branch of Minas Gerais reinforce behaviors that require leaders to use transactional leadership style. In this sense, team members end up successfully associating the philosophy of people management, which is centered in the link between performance and rewards. In other words, the people management policies and practices, characterized by focusing on the development of meritocracy and valorization of the employees, is heavily based on managerial tools that offer gains for those who have additional training and achieve higher performance. It creates a relationship based on the exchange between state and employee, which in turn, is extended to the leader-follower dyad. The same happens to the performance policy, since rewarding systematically for goal achievement reinforces the idea of exchange, empowering the transactional leader.

The results suggest that the performance evaluation run by the government might be overvalued, since leaders and non-leader employees think that their own team performance is lower than the officially measured performance. Given this, it is important to emphasize that the performance 
system is not necessarily linked to the reward system. Performance can also be measured for the purpose of providing input to support teams and individuals development (Hipólito \& Reis, 2002). Despite the development perspective of the Executive Branch of Minas Gerais, the results of this research lead to the conclusion that performance evaluation measurement is more associated to the idea of employees obtaining financial returns. Thus, it is up to those responsible for designing people management policies to provide forms of recognition other than financial rewards to support the employees' development and generate results for the population. The results of this study suggest that public administration should use official data on performance appraisal with care, as it might be overestimated. In addition, managers are also responsible for developing mechanism to increase the reliability of the official performance evaluation practice.

The results also offer important information for senior managers, as they indicate that leaders think that transformational style is intrinsically related to team performance. This is important to people management policy regarding leadership development, because leaders value behaviors, such as sharing visions, creating meanings and ways to promote development, and giving individualized attention. On the other hand, when dealing with their followers, leaders should focus their energies on follow-up and orientation, distribution of rewards, motivating, and focusing on relationships to achieve organizational goals.

Regarding the hierarchy within the state public administration, the research findings indicate that the negotiating leader is responsible for the best performance of the work teams. However, when managers achieve upper levels, the transformational style seems to be better suited to improve the other managers' performance. As a consequence, it is the responsibility of the public administration, responsible for people management, to identify the best style of leadership for each hierarchical level, offering appropriate managerial training for the position occupied. Employees promoted from a team manager position to a higher level may require drastic change of behavior, resulting in high levels of stress and even reduced performance.

At this point, it is also important to highlight the low levels of laissez-faire leadership style, or not-leadership. In this context, the Executive Branch of Minas Gerais experiences do not reinforce this leadership style. This result is positive, but at the same time, it still requires action by those in charge of people management policy in order to reduce the presence of laissez-faire characteristics in managers.

This research, while contributing to the analysis of leadership styles and team performance in state level executive public administration, has some 
limitations. Firstly, the instrument used - MLQ - which was used to identify the leadership styles of public managers, was developed in the United States. Therefore, it was structured from historical, social and cultural milestones of the American reality. Such limitation is acknowledged, although its adoption, among other possibilities studied, has been important insofar as it is a widely tested and validated instrument. In addition, the management models contemporaneously used by Brazilian organizations are based on the American literature as an important source. Another limitation concerns one of the target audiences of this survey, which focused its attention on formal leaders. Thus, we had no intention of identifying informal leaders who can also generate some type of influence and, consequently, end up impacting team performance.

This research provides other considerations, not due to its limitations, but to the richness of the information found. Future research might expand into the reasons that led to different perceptions of leaders and followers, regarding the identification of leadership styles and their impact on team performance. In addition to studies that combine the answers of each leader to their respective team, the characteristics of the teams can be investigated to analyze if any pattern emerges to explain the findings of this research.

Finally, future research may also assess whether other Brazilian states that adopted management models similar to the models of Minas Gerais show the same results in relation to the differences in perceptions between leaders and followers, in relation to which leadership style is associated to higher performance. In this way, it may be possible to understand whether the results of this research are related to the management model adopted, or if the results portray only a peculiarity of the State of Minas Gerais.

\section{DESEMPENHO E ESTILO DE LIDERANÇA: QUANDO LÍDERES E LIDERADOS DIVERGEM}

\section{RESUMO}

Objetivo: O objetivo desta pesquisa é analisar, no setor público, como o desempenho das equipes é influenciado pelos estilos de liderança, confrontando a perspectiva dos líderes com a dos liderados.

Originalidade/lacuna/relevância/implicações: A principal contribuição deste estudo é comparar as perspectivas dos líderes e dos liderados, relacionando o nível de desempenho das equipes de trabalho com o esti- 
lo de liderança no setor público. Esta pesquisa oferece dados empíricos que podem auxiliar os gestores no desenvolvimento de políticas e práticas de gestão de pessoas voltadas para o desenvolvimento de lideranças e redução da lacuna entre líderes e liderados.

Principais aspectos metodológicos: Realizou-se uma pesquisa com 315 servidores do poder executivo do estado de Minas Gerais. Foram aplicados questionários padronizados baseados em instrumentos amplamente testados.

Síntese dos principais resultados: Os resultados indicam que, para os líderes, o estilo de liderança transformacional é responsável pelo elevado desempenho das equipes, confirmando a literatura sobre liderança. $\mathrm{Na}$ perspectiva dos liderados, o alto desempenho é resultante da liderança transacional, isto é, o líder negociador é preferido ao líder motivador. Finalmente, foi possível identificar ainda que os níveis de desempenho medidos pelo governo são superestimados quando confrontados com a medição realizada pelos pesquisadores.

Principais considerações/conclusões: A dinâmica de gestão de pessoas por resultado na administração pública reforça comportamentos que exigem líderes transacionais para garantir o desempenho das equipes, contrariando a teoria sobre estilos de liderança e desempenho. No entanto, quando o gestor é promovido, as características transformacionais parecem ser mais indicadas para melhorar o desempenho das equipes de gestores.

\section{PALAVRAS-CHAVE}

Liderança. Estilos de liderança. Desempenho. Desempenho de equipes. Gestão de pessoas.

\section{DESEMPEÑO Y ESTILO DE LIDERAZGO: ¿CUANDO LÍDERES Y SEGUIDORES DIVERGE?}

\section{RESUMEN}

Objetivo: El objetivo de esta investigación es analizar, en el sector público, como el desempeño del equipo se ve influenciada por los estilos de liderazgo, en la perspectiva de los líderes y en la perspectiva de los seguidores. 
Originalidad/laguna/relevancia/implicaciones: La principal contribución de este estudio es comparar los puntos de vista de los dirigentes y los seguidores, en relación con el nivel de rendimiento de los equipos de trabajo y el estilo de liderazgo en el sector público. Esta investigación ofrece datos empíricos que pueden ayudar a los administradores a desarrollar políticas y prácticas de gestión con el fin de mejorar el rendimiento de liderazgo y reducir la brecha entre los líderes y los seguidores.

Principales aspectos metodológicos: Llevamos a cabo una encuesta con 315 servidores del Poder Ejecutivo del estado de Minas Gerais. Se aplicaron cuestionarios estandarizados basados en instrumentos ampliamente probados disponibles en la literatura.

Síntesis de los principales resultados: Los resultados indican que para los líderes de estilo de liderazgo transformacional es el responsable de los equipos de alto rendimiento, lo que confirma la literatura sobre liderazgo. En la perspectiva de los seguidores, el alto rendimiento es resultante de liderazgo transaccional, lo que demuestra que lo líder negociador se prefiere en lugar de lo líder motivador. Finalmente, fue posible identificar que los niveles de desempeño medidos por el gobierno se sobrestiman en comparación con las medidas realizada por esta investigación. Principales consideraciones/conclusiones: La dinámica de la gestión de personal en la administración pública refuerza los comportamientos que requieren líderes transaccionales para asegurar el rendimiento del equipo, lo que contradice la teoría de los estilos de liderazgo y rendimiento. Sin embargo, cuando se promueve el gerente, características transformacionales parecen ser más adecuadas para mejorar el rendimiento de los jefes de equipo.

\section{PALABRAS CLAVE}

Liderazgo. Estilos de liderazgo. Desempeño. Desempeño del equipo. Gestión de personas.

\section{REFERENCES}

Babbie, E. (2015). The practice of social research. (14th ed.). Boston: Cengage Learning.

Bass, B. M. (1985). Leadership and performance beyond expectations. New York: The Free Press. 
Bass, B. M., \& Avolio, B. J. (2000). MLQ: Multifactor questionnaire. Redwood City: Mind Garden.

Bass, B. M., Avolio, B. J., Jung, D. I., \& Berson, Y. (2003). Predicting unit performance by assessing transformational and transactional leadership. Journal of Applied Psychology, 88(2), 207-218. DOI: http://doi.org/10.1037/ 0021-9010.88.2.207.

Bergamini, C. W. (1994). Liderança: a administração de sentido. Revista de Administração de Empresas, 34(3), 102-114.

Brannick, M. T., \& Prince, C. (1994). An overview of team performance measurement. In T. M. Brannick, E. Salas \& C. Prince (Eds.). Team performance assessment and measurement: theory, methods, and applications (pp. 3-18). Mahwah: Lawrence Erlbaum Associates, Inc.

Collis, J., \& Hussey, R. (2005). Pesquisa em administração. Porto Alegre: Bookman. Conger, J. A., \& Kanungo, R. N. (1987). Toward a behavioral theory of charismatic leadership in organizational settings. Academy of Management Review, 12(4), 637-647. DOI: http://doi.org/10.5465/AMR.1987.4306715.

Creswell, J. W. (2013). Research design: qualitative, quantitative, and mixed methods approaches. (4th ed). Thousand Oaks: Sage Publications.

Dionne, S. D., Sayama, H., Hao, C., \& Bush, B. J. (2010). The role of leadership in shared mental model convergence and team performance improvement: an agent-based computational model. The Leadership Quarterly, 21 (6), 1035-1049. DOI: http://doi.org/10.1016/j.leaqua.2010.10.007.

Dionne, S. D., Yammarino, F. J., Atwater, L. E., \& Spangler, W. D. (2004). Transformational leadership and team performance. Journal of Organizational Change Management,17(2),177-193.DOI:http://doi.org/10.1108/09534810410530601.

Duarte, K., Lemos, C., Marini, C., \& Martins, H. F. (2006). Acordo de resultados. In R. Vilhena (Ed.). O choque de gestão em Minas Gerais: políticas da gestão pública para o desenvolvimento. Belo Horizonte: UFMG.

Dutra, J. S. (2010). Competências: conceitos e instrumentos para a gestão de pessoas na empresa moderna. São Paulo: Atlas.

Fernandes, B. R. (2013). Gestão estratégica de pessoas com foco em competências. Belo Horizonte: Elsevier - Campus.

Fonseca, A. M. de O., Porto, J. B., \& Barroso, A. C. (2012). O efeito de valores pessoais nas atitudes perante estilos de liderança. Revista de Administração Mackenzie, 13(3), 122-149. DOI: http://doi.org/10.1590/S167869712012000300007.

Gil, A. C. (2008). Métodos e técnicas de pesquisa social. (6th ed). São Paulo: Atlas. Habermas, J. (2010). Teoria de la acción comunicativa: racionalidade de la cción y racionalización social. (v. 1). Madri: Taurus. 
Hair, J. F., Black, W. C., Babin, B. J., Anderson, R. E., \& Tatham, R. L. (2006). Multivariate data analysis (6th ed). Upper Saddle River: Pearson Prentice Hall. Hamel, G. (1997). Reinventing the basis for competition. In R. Gibson (Ed.). Re-thinking the future. London: Nicholas Brealey.

Hipólito, J. A., \& Reis, G. G. A. (2002). A avaliação como instrumento de gestão. In M. T. L. Fleury (Ed.). As pessoas na organização. (pp. 73-86). São Paulo: Gente. Hodgkinson, G. P., \& Healey, M. P. (2008). Cognition in organizations. Annual Review of Psychology, 59(1), 387-417. DOI: http://doi.org/10.1146/ annurev.psych.59.103006.093612.

Hogan, R., Curphy, G. J., \& Hogan, J. (1994). What we know about leadership: effectiveness and personality. American Psychologist, 49(6), 493-504. DOI: http://doi.org/10.1037/0003-066X.49.6.493.

Jones, D., \& Rudd, R. (2008). Transactional, transformational, or laissez-faire leadership: an assessment of College of Agriculture Academic Program Leaders'(Deans) leadership styles. Journal of Agricultural Education, 49(2), 88-97. Judge, T. A., Bono, J. E., Ilies, R., \& Gerhardt, M. W. (2002). Personality and leadership: a qualitative and quantitative review. Journal of Applied Psychology, 87(4), 765-780. DOI: http://doi.org/10.1037/0021-9010.87.4.765.

Jung, D. I., \& Avolio, B. J. (1999). Effects of leadership style and followers' cultural orientation on performance in group and individual task conditions. Academy of Management Journal, 42(2), 208-218. DOI: http://doi.org/ $10.2307 / 257093$.

Kirkbride, P. (2006). Developing transformational leaders: the full range leadership model in action. Industrial and Commercial Training, 38(1), 23-32. DOI: http://doi.org/10.1108/00197850610646016.

Klein, K. J., \& Kozlowski, S. W. J. (2000). From micro to meso: critical steps in conceptualizing and conducting multilevel research. Organizational Research Methods, 3(3), 211-236. DOI: http://doi.org/10.1177/109442810033001.

Laine, T., Korhonen, T., \& Martinsuo, M. (2016). Managing program impacts in new product development: an exploratory case study on overcoming uncertainties. International Journal of Project Management, 34(4), 717-733. DOI: http://doi.org/10.1016/j.ijproman.2016.02.011.

Lebas, M., \& Euske, K. (2002). A conceptual and operational delineation of performance. In A. D. Neely (Ed.). Business performance measurement: theory and practice. New York: Cambridge University Press.

Margerison, C., Dick, M., \& Davies, R. (1995). Focus on team appraisal. Team Performance Management, 1 (4), 13-18. 
Marques, A. L., Borges, R., Morais, K., \& Silva, M. C. (2014). Relações entre resistência a mudança e comprometimento organizacional em servidores públicos de Minas Gerais. Revista de Administração Contemporânea, 18(2), 161175. DOI: http://doi.org/10.1590/S1415-65552014000200004.

Martins, H. F. (2014). Burocracia e a revolução gerencial - a persistência da dicotomia entre política e administração. Revista Do Serviço Público, 48(1), 42-78. Moynihan, D. P., Wright, B. E., \& Pandey, S. K. (2012). Working within constraints: can transformational leaders alter the experience of red tape?. International Public Management Journal, 15(3), 315-336. DOI: http://doi.org/10.1 080/10967494.2012.725318.

Murphy, K. R. (2008). Explaining the weak relationship between job performance and ratings of job performance. Industrial and Organizational Psychology, 1 (2), 148-160. DOI: http://doi.org/10.1111/j.1754-9434.2008.00030.x.

Niemeyer, J. R. L., \& Cavazotte, F. de S. C. N. (2016). Ethical leadership, leader-follower relationship and performance: a study in a telecommunications company. Revista de Administração Mackenzie, 17(2), 67-92. DOI: http:// doi.org/10.1590/1678-69712016/administracao.v17n2p67-92.

Oliveira, F. B. de, Sant'Anna, A. de S., \& Vaz, S. L. (2010). Liderança no contexto da nova administração pública: uma análise sob a perspectiva de gestores públicos de Minas Gerais e Rio de Janeiro. Revista de Administração Pública, 44(6), 1453-1475. DOI: http://doi.org/10.1590/S003476122010000600009 .

Özaralli, N. (2003). Effects of transformational leadership on empowerment and team effectiveness. Leadership \& Organization Development Journal, 24(6), 335-344. DOI: http://doi.org/10.1108/01437730310494301.

Ribeiro, L. M., Chaves, L. S., Gama, M. A. A., \& Dias, M. A. M. J. (2011). Gestão de pessoas no Governo do Estado de Minas Gerais: panorama histórico e evolutivo a partir da implantação do choque de gestão. Congresso CONSAD de Gestão Pública, Brasília - DF, Brasil, IV.

Ross, S. M., \& Offermann, L. R. (1997). Transformational leaders: measurement of personality attributes and work group performance. Personality and Social Psychology Bulletin, 23(10), 1078-1086. DOI: http://doi.org/10.1177/ 01461672972310008.

Sant'anna, A. D. S., Campos, M. S., \& Lótfi, S. (2012). Liderança: o que pensam executivos brasileiros sobre o tema?. Revista de Administração Mackenzie, 13(6), 48-76. DOI: http://doi.org/10.1590/S1678-69712012000600004.

Shen, M.-J., \& Chen, M.-C. (2007). The relationship of leadership, team trust and team performance: a comparison of the service and manufacturing 
industries. Social Behavior and Personality: An International Journal, 35(5), 643658. DOI: http://doi.org/10.2224/sbp.2007.35.5.643.

Somech, A. (2006). The effects of leadership style and team process on performance and innovation in functionally heterogeneous teams. Journal of Management, 32(1), 132-157. DOI: http://doi.org/10.1177/0149206305277799.

Tost, L. P., Gino, F., \& Larrick, R. P. (2013). When power makes others speechless: the negative impact of leader power on team performance. Academy of Management Journal, 56(5), 1465-1486. DOI: http://doi.org/10.5465/ amj.2011.0180.

Ulrich, D., \& Lake, D. (1990). Organizational capability: competing from the inside out. New York: John Wiley \& Sons.

Van Seters, D. A., \& Field, R. H. G. (1990). The evolution of leadership theory. Journal of Organizational Change Management, 3(3), 29-45. DOI: http:// doi.org/10.1108/09534819010142139.

Weick, K. E., \& Roberts, K. H. (1993). Collective mind in organizations: heedful interrelating on flight decks. Administrative Science Quarterly, 38(3), 357-381. DOI: http://doi.org/10.2307/2393372.

Weick, K. E., Sutcliffe, K. M., \& Obstfeld, D. (2005). Organizing and the process of sensemaking. Organization Science, 16(4), 409-421. DOI: http:// doi.org/10.1287/orsc.1050.0133.

Yukl, G. (1989). Managerial leadership: a review of theory and research. Journal of Management, 15(2), 251-289. DOI: http://doi.org/10.1177/ 014920638901500207.

\section{(APPENDIX I)}

MEASUREMENT MODEL STANDARDIZED FACTORIAL LOADINGS AND RELIABILITY

\begin{tabular}{llcccc}
\hline Construct & Items & $\begin{array}{c}\text { Factorial } \\
\text { loadings }\end{array}$ & $\begin{array}{c}\text { Variance } \\
\text { t-value* }\end{array}$ & $\begin{array}{c}\alpha \text { de } \\
\text { explained } \\
\text { Cronbach }\end{array}$ \\
\hline $\begin{array}{llccc}\text { Transformational } \\
\text { leadership }\end{array}$ & Idealized influence & 0.91 & 29.96 & 0.87 & 0.91 \\
& Inspirational motivation & 0.94 & 30.93 & & \\
& Intellectual stimulation & 0.93 & 30.14 & & \\
& Individual consideration & 0.95 & 31.44 & & \\
\hline
\end{tabular}

(continue) 


\section{(APPENDIX I (conclusion))}

\section{MEASUREMENT MODEL STANDARDIZED FACTORIAL} LOADINGS AND RELIABILITY

\begin{tabular}{|c|c|c|c|c|c|}
\hline Construct & Items & $\begin{array}{l}\text { Factorial } \\
\text { loadings }\end{array}$ & t-value* & $\begin{array}{l}\text { Variance } \\
\text { explained }\end{array}$ & $\begin{array}{c}\alpha \text { de } \\
\text { Cronbach }\end{array}$ \\
\hline \multirow[t]{2}{*}{$\begin{array}{l}\text { Transactional } \\
\text { leadership }\end{array}$} & $\begin{array}{l}\text { Contingent reward } \\
\text { Administration by }\end{array}$ & 0.89 & 18.54 & 0.7 & 0.74 \\
\hline & exception & 0.78 & 18.22 & 0.52 & 0.71 \\
\hline \multirow[t]{3}{*}{ Laissez-faire } & LF_I & 0.75 & 15.89 & 0.52 & 0.71 \\
\hline & LF_2 & 0.72 & 15.73 & & \\
\hline & LF_3 & 0.68 & 15.21 & & \\
\hline \multirow[t]{5}{*}{ Performance } & Focus on results & 0.93 & 29.74 & 0.79 & 0.93 \\
\hline & Focus on clients & 0.85 & 23.69 & & \\
\hline & Innovation & 0.91 & 28.25 & & \\
\hline & Team work & 0.92 & 29.32 & & \\
\hline & Professional commitment & 0.84 & 23.01 & & \\
\hline \multicolumn{6}{|c|}{$\chi 2 \mathrm{df}=2.9 ; \mathrm{RMSEA}=0.073(\mathrm{Cl} 0.067-0.092) ; \mathrm{CFI}=0.93 ; \mathrm{TLI}=0.95 ; \mathrm{SRMR}=0.038$} \\
\hline
\end{tabular}

Note. Source: Research data * $\mathrm{p}<0.001$

Note: ${ }^{\star} p<0.001$

Source: Elaborated by the authors. 